\title{
Concrete In Hot Weather Conditions-Challanges - Precautions
}

\author{
Dr. S. Vijaya Mohan Rao \\ Professor and Head of Department in "Siddhartha Institute of Engineering \& Technology”, Hyderabad, Telangana state, India.
}

\begin{abstract}
In general, Concrete sets as the cement hydrates, and is an exothermic reaction, means it generates heat reaction goes quickly when the concrete is hot condition. The main reason with the concrete's strength and setting time is not really the air temperature but the concrete temperature. During the time of cement hydration it sucks up water and forms crystals around the aggregate particles as shown in fig 1. The crystals grow faster but do not have time to grow strong when it is hot and is rapid. The 28day strength suffers even though early strength is higher. If the concrete is about $16^{\circ}$ hotter than normal (for example, $86^{\circ}$ instead of $70^{\circ}$ ), the compressive strength will be about $10 \%$ lower. The slump decreases rapidly as the cement set up In hot weather, and the mixing water is more needed. It can also contribute to lower strengths (another $10 \%$ lower), can lead to variations in water content which can result differences in concrete color between adjacent pours. Next problem in hot weather is drying of surface, comes with a caveat. If the concrete is warm, sun is shining and hot dry wind across the concrete, it is likely to get more drying and surface shrinkage. By the help of nomograph from ACI 305 (Fig 8) the relative humidity, concrete temperature, air temperature and wind velocity, it arrive at rate of evaporation. The shrinkage cracking is possible when the rate is greater than 0.1 pounds per square foot per hour. Hot dry sub grades and formwork can also result in cracks by absorbing water from the mix. Another problem with heat and concrete is thermal differentials. All that means is that one part of the concrete mass is warmer than another part. If the differential is greater than about $20^{\circ} \mathrm{F}$ then the concrete likely to get cracks. This tends to be a particular problem in mass concrete (members thicker than about 18 inches).
\end{abstract}

Keywords: Bleeding, Curing, Evaporation, Finishing, Mixture Proportioning, Plastic Shrinkage Cracking, Trial Batch, Temperature.

\section{Introduction}

Weather conditions at a jobsite-hot or cold, windy or calm, dry or humid - may be vastly different from the optimum conditions assumed at the time a concrete mix is specified designed, or selected, or from laboratory conditions in which concrete specimens are stored and tested. In the concrete business, hot weather creates situations that require special procedures for proper mixing, placing, finishing, and curing. Hot weather conditions adversely influence concrete quality primarily by accelerating the rate of moisture loss and rate of cement hydration that occur at the higher temperatures. Detrimental hot weather conditions include:

- High ambient temperature, $\bullet$ High concrete temperature,

- Low Relative Humidity, • High Wind Speed,

\subsection{Pouring of Concreting in Hot-Weather - Difficulties}

Hot weather conditions can create difficulties in fresh concrete, such as:

- Increased water demand

- Accelerated slump loss leading to the addition of water on the jobsite

- Increased rate of setting resulting in placing and finishing difficulties.

- Increased tendency for plastic cracking

- Critical need for prompt early curing

- Difficulties in controlling entrained air

- Increased concrete temperature resulting in long-term strength loss

- Increased potential for thermal cracking

Adding water to the concrete at the jobsite can adversely affect properties and serviceability of the hardened concrete, resulting in:
- Decreased strength from higher water to cement ratio

- Decreased durability due to cracking

- Increased permeability

- Non-uniform surface appearance

- Increased tendency for drying shrinkage

- Reduced abrasion resistance from tendency to sprinkle water during finishing.

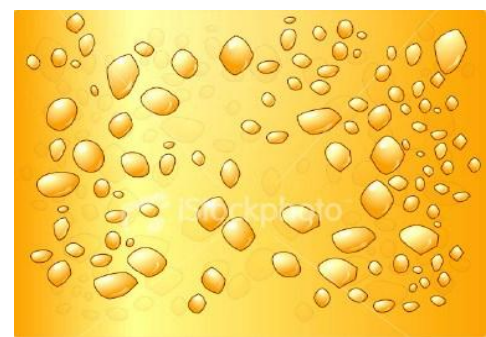

Figure 1

\subsection{When To Take Precautions}

During hot weather the most favourable temperature for achieving high quality freshly mixed concrete is usually lower than can be obtained without artificial cooling. A concrete temperature of $10^{\circ} \mathrm{C}$ to $15^{\circ} \mathrm{C}\left(50^{\circ} \mathrm{F}\right.$ to $\left.60^{\circ} \mathrm{F}\right)$ is desirable to maximize beneficial mix properties, but such temperature are not always practical. Many specifications require only that concrete when placed should have a temperature of less than $29^{\circ} \mathrm{C}$ to $32^{\circ} \mathrm{C}\left(85^{\circ} \mathrm{F}\right.$ to $\left.90^{\circ} \mathrm{F}\right)$. The ASTM C 94 (AASHTO M 157) specifications for ready mixed concrete notes in some situations difficulty may be encountered when concrete temperatures approach $32^{\circ} \mathrm{C}$ $\left(90^{\circ} \mathrm{F}\right)$. However, this specification does not mandate a maximum concrete temperature unless heated aggregates or heated water are used. 


\section{International Journal of Science and Research (IJSR) \\ ISSN (Online): 2319-7064 \\ Index Copernicus Value (2013): 6.14 | Impact Factor (2014): 5.611}

Precautions should be planned in advance to counter the effects of a high concrete temperature when the concrete placed is somewhere between $25^{\circ} \mathrm{C}$ and $35^{\circ} \mathrm{C}\left(77^{\circ} \mathrm{F}\right.$ and $95^{\circ} \mathrm{F}$ ). Last-minute attempts to prevent hot-weather damage are rarely performed soon enough. If acceptable field data is not available, the maximum temperature limit should be established for conditions at the jobsite; this should be based on trial-batch tests at the temperature and for the typical concrete section thickness anticipated, rather than on ideal temperatures of $20^{\circ} \mathrm{C}$ to $30^{\circ} \mathrm{C}\left(68^{\circ} \mathrm{F}\right.$ to $\left.86^{\circ} \mathrm{F}\right)$ cited in ASTM C 192 (AASHTO T 126). If possible large batches should be made to measure mix properties at time intervals to establish the relationship for the property of interest as a function of time at various batch temperatures of interest. This process will establish the maximum allowable time to discharge concrete after batching for various concrete temperatures.

The following are the precautions will reduce the potential problems of hot-weather concreting.

- Use materials and mix proportions that have a good record in hot-weather conditions.

- Cool the concrete or one or more of its ingredients.

- Use a concrete consistency that allows rapid placement and consolidation.

- $\quad$ Reduce the time of transport, placing and finishing as much as possible.

- Schedule concrete placements to limit exposure to atmospheric conditions, such as at night or during favourable weather conditions ( Fig 2)

- Consider methods to limit moisture loss during placing and finishing, such as sunshades, windscreens, fogging, or spraying.

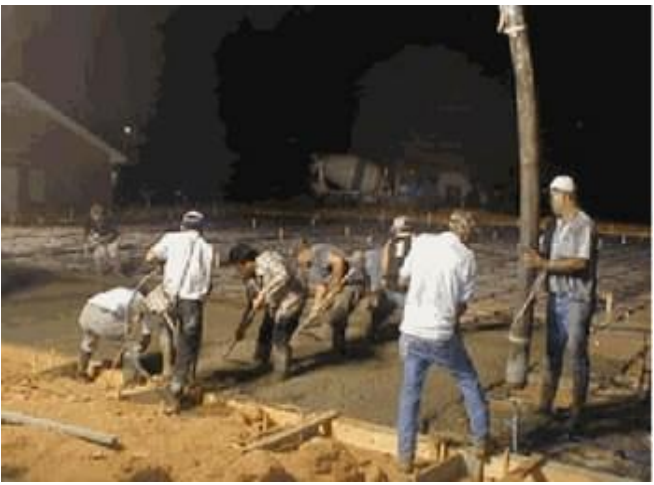

Figure 2: Pouring of concrete in Night

\section{Effects of High Concrete Temperatures}

As concrete temperature increases there is a loss in slump that is often unadvisedly compensated for by adding water to the concrete at the jobsite. At higher temperatures a greater amount of water is required to hold slump constant than is needed at lower temperatures. Adding water without adding cement results in a higher water-cement ratio, thereby lowering the strength at all ages and adversely affecting other desirable properties of the hardened concrete. This is in addition to the adverse effect on strength at later ages due to the higher temperature, even without the addition of water. Adding cement to compensate for the use of additional mix water may not be enough to achieve the desired concrete properties because additional cement will further increase the concrete temperature and water demand.
If the temperature of freshly mixed concrete is increased from $10^{\circ} \mathrm{C}$ to $38^{\circ} \mathrm{C}\left(50^{\circ} \mathrm{F}\right.$ to $100^{\circ} \mathrm{F}$ ) (as shown in Fig. 3 ) about $20 \mathrm{~kg} / \mathrm{m} 3$ (33 lb/yd3) of additional water is needed to maintain the same 75-mm (3-in.) slump. This additional water could reduce strength by $12 \%$ to $15 \%$ and produce a compressive strength cylinder test result that may not comply with specifications.

High temperatures of freshly mixed concrete increase the rate of setting and shorten the length of time within which the concrete can be transported, placed, and finished Setting time can be reduced by Two or more hours with a $10^{\circ} \mathrm{C}$ $\left(18^{\circ} \mathrm{F}\right)$ increase in concrete temperature shown in Fig 4. Concrete should remain plastic long enough so that each layer can be placed without development of cold joints or discontinuities in the concrete. Retarding admixtures, ( ASTM C 494 (AASHTO M 194) Type B, and hydration control admixtures can be beneficial in offsetting the accelerating effects of high temperature.

In hot weather, there is an increased tendency for cracks to form both before and after hardening. Rapid evaporation of water from freshly placed concrete can cause plasticshrinkage cracks before the surface has hardened. Cracks may also develop in the hardened concrete because of.

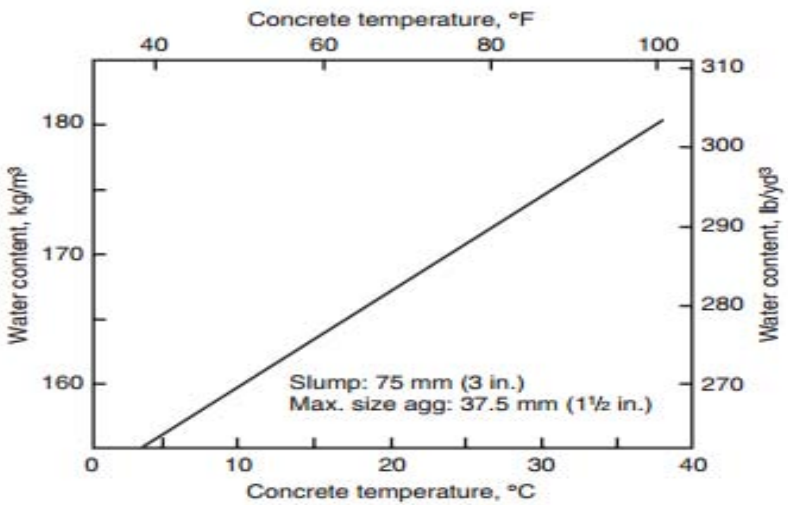

Figure 3: The water requirement of a concrete mixture increases with an increase in concrete temperature Bureau of Reclamation (1981).

increased drying shrinkage due to higher water contents or thermal volume changes as the concrete cools. Air entrainment is also affected in hot weather. At elevated temperatures, an increase in the amount of air-entraining admixture is required to produce a given air content. The effect of high initial concrete temperatures on compressive strength is shown in fig 5 . The concrete temperatures at the time of mixing, casting, and curing were $23^{\circ} \mathrm{C}\left(73^{\circ} \mathrm{F}\right), 32^{\circ} \mathrm{C}$ $\left(90^{\circ} \mathrm{F}\right), 41^{\circ} \mathrm{C}\left(105^{\circ} \mathrm{F}\right)$, and $49^{\circ} \mathrm{C}\left(120^{\circ} \mathrm{F}\right)$. After 28 days, the specimens were all moist-cured at $23^{\circ} \mathrm{C}\left(73^{\circ} \mathrm{F}\right)$ until the 90 day and one-year test ages. The tests, using identical concretes of the same water-cement ratio, show that while higher concrete temperatures give higher early strength than concrete at $23^{\circ} \mathrm{C}\left(73^{\circ} \mathrm{F}\right)$, at later ages concrete strengths are lower. If the water content had been increased to maintain the same slump (without increasing cement content), the reduction in strength would have been even greater than shown. 
International Journal of Science and Research (IJSR)

ISSN (Online): 2319-7064

Index Copernicus Value (2013): 6.14 | Impact Factor (2014): 5.611

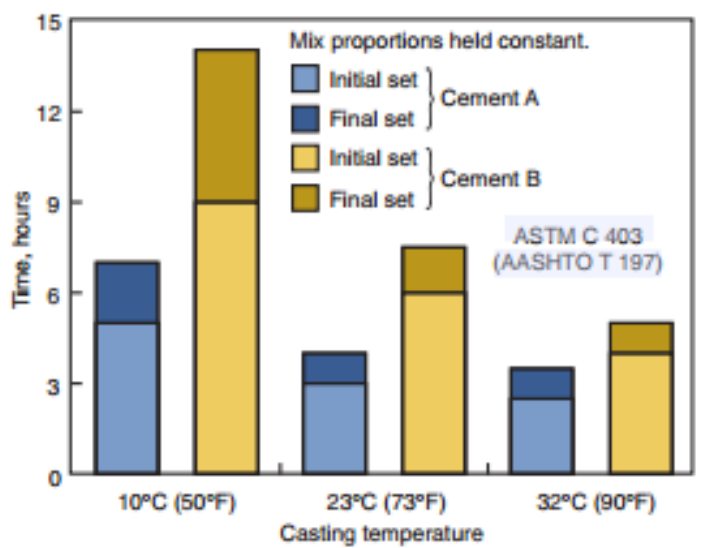

Figure 4: Effect of concrete temperature on setting time (Burg 1996)

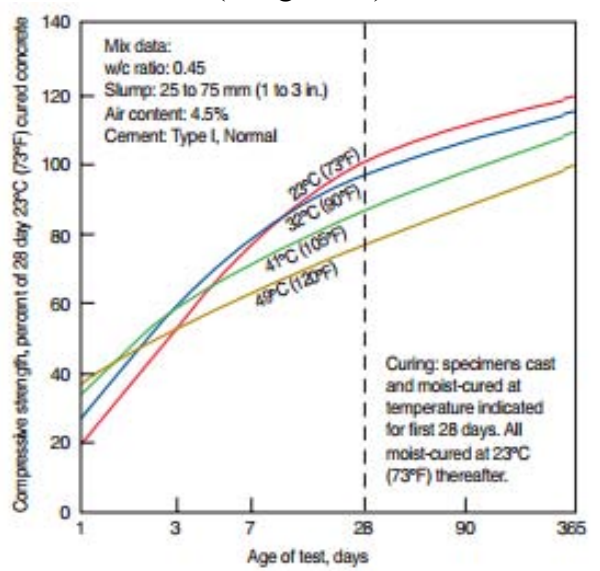

Figure 5: Effect of high concrete temperatures on compressive strength at various ages (Klieger 1958).

Steps should be taken to make sure ASTM C 31 (AASHTO $\mathrm{T}$ 23) procedures are followed regarding initial curing of strength specimens for acceptance or quality control testing at $16^{\circ} \mathrm{C}$ to $27^{\circ} \mathrm{C}\left(60^{\circ} \mathrm{F}\right.$ to $\left.80^{\circ} \mathrm{F}\right)$. If the initial 24 hour curing is at $38^{\circ} \mathrm{C}\left(100^{\circ} \mathrm{F}\right)$, the 28 -day compressive strength of the test specimens may be $10 \%$ to $15 \%$ lower than if cured at the required ASTM C 31 (AASHTO T 23) curing temperatures (Gaynor 1985).

\subsection{Cooling Concrete Materials}

The usual method of cooling concrete is to lower the temperature of the concrete materials before mixing. One or more of the ingredients should be cooled. In hot weather the aggregates and mixing water should be kept as cool as practicable; these materials have a greater influence on concrete temperature after mixing than other ingredients.

The contribution of each ingredient in a concrete mixture to the temperature of the freshly mixed concrete is related to the temperature, specific heat, and quantity of each material. Fig. 6, shows graphically the effect of temperature of materials on the temperature of fresh concrete. It is evident that although concrete temperature is primarily dependent upon the aggregate temperature, cooling the mixing water can be effective. The approximate temperature of concrete can be calculated from the temperatures of its ingredients by using the following equation (NRMCA 1962):

$$
T=\frac{0.22\left(T_{\mathrm{a}} M_{\mathrm{a}}+T_{\mathrm{c}} M_{\mathrm{c}}\right)+T_{\mathrm{w}} M_{\mathrm{w}}+T_{\mathrm{wa}} M_{\text {wa }}}{0.22\left(M_{\mathrm{a}}+M_{\mathrm{c}}\right)+M_{w}+M_{\text {wa }}} \text { where }
$$

$T=$ temperature of the freshly mixed concrete, ${ }^{\circ} \mathrm{C}\left({ }^{\circ} \mathrm{F}\right)$

$T_{a}, T_{c}, T_{w}$, and $T_{w a}=$ temperature in ${ }^{\circ} \mathrm{C}\left({ }^{\circ} \mathrm{F}\right)$ of aggregates, cement, added mixing water, and free water on aggregates, respectively

$M_{\mathrm{a}}, M_{\mathrm{c}}, M_{\mathrm{w}}$, and $M_{\mathrm{wa}}=$ mass, $\mathrm{kg}(\mathrm{lb})$, of aggregates, cementing materials, added mixing water, and free water on aggregates, respectively

Example calculations for initial concrete temperature are shown in Table 1.

Of all the materials in concrete, water is the easiest to cool. Even though it is used in smaller quantities than the other ingredients, cold water will produce a moderate reduction in the concrete temperature. Mixing water from a cool source should be used. It should be stored in tanks that are not exposed to the direct rays of the sun. Tanks and pipelines carrying mixing water should be buried, insulated, shaded, or painted white to keep water as cool as practical. Water can be cooled by refrigeration, liquid nitrogen, or ice. Cooling the mix water temperature $2.0^{\circ} \mathrm{C}$ to $2.2^{\circ} \mathrm{C}\left(3.5^{\circ} \mathrm{F}\right.$ to $4^{\circ} \mathrm{F}$ ) will usually lower the concrete temperature about $0.5^{\circ} \mathrm{C}\left(1^{\circ} \mathrm{F}\right)$. However, because mix water is such a small percentage of the total mixture, it is difficult to lower concrete temperatures more than about $4.5^{\circ} \mathrm{C}\left(8^{\circ} \mathrm{F}\right)$ by cooling the water alone. Ice can be used as part of the mixing water provided it is completely melted by the time mixing is completed.

Table 1A. (Metric). Effect of Temperature of Materials on Initial Concrete Temperature

\begin{tabular}{|c|c|c|c|c|c|}
\hline Material & Mass, $M, \mathrm{~kg}$ & $\begin{array}{c}\text { Specific heat } \\
\mathrm{kJ} / \mathrm{kg} \cdot \mathrm{K}\end{array}$ & $\begin{array}{c}\text { Joules to vary } \\
\text { temperature, } 1^{\circ} \mathrm{C}\end{array}$ & $\begin{array}{c}\text { Initial } \\
\text { temperature of } \\
\text { material, } T,{ }^{\circ} \mathrm{C}\end{array}$ & $\begin{array}{l}\text { Total joules } \\
\text { in material }\end{array}$ \\
\hline & (1) & (2) & $\begin{array}{c}\text { (3) } \\
\text { Col.1 } \times \text { Col. } 2\end{array}$ & (4) & $\begin{array}{c}\text { (5) } \\
\text { Col. } 3 \times \text { Col. } 4\end{array}$ \\
\hline $\begin{array}{l}\text { Cement } \\
\text { Water } \\
\text { Total }\end{array}$ & $\begin{array}{l}335\left(M_{c}\right) \\
123\left(M_{w}\right)\end{array}$ & $\begin{array}{l}0.92 \\
4.184\end{array}$ & $\begin{array}{r}308 \\
515 \\
\end{array}$ & $\begin{array}{l}66\left(T_{C}\right) \\
27\left(T_{w}\right) \\
27\left(T_{0}\right)\end{array}$ & $\begin{array}{l}20,328 \\
13,905 \\
45,684\end{array}$ \\
\hline Total aggregate & $1839\left(M_{2}\right)$ & 0.92 & $\frac{1692}{2515}$ & $27\left(T_{a}\right)$ & $\frac{45,684}{79,917}$ \\
\hline
\end{tabular}

Initial concrete temperature $=\frac{79,917}{2515}=31.8^{\circ} \mathrm{C}$

To achieve $1^{\circ} \mathrm{C}$ reduction in initial concrete temperature: Cement temperature must be lowered $=\frac{2515}{308}=8.2^{\circ} \mathrm{C}$ Or water temperature dropped $=\frac{2515}{515}=4.9^{\circ} \mathrm{C}$ Or aggregate temperature cooled $=\frac{2515}{1692}=1.5^{\circ} \mathrm{C}$

When using crushed ice, care must be taken to store it at a temperature that will prevent the formation of lumps. When ice is added as part of the mixing water, the effect of the heat of fusion of the ice must be considered so the equation for temperature of fresh concrete is modified as follows.

$$
\begin{aligned}
& T\left(C^{\circ}\right)=\frac{0.22\left(T_{a} M_{a}+T_{c} M_{c}\right)+T_{w} M_{w}+T_{w a} M_{w a}-80 M_{i}}{0.22\left(M_{a}+M_{c}\right)+M_{w}+M_{w a}+M_{i}} \\
& T\left(F^{\circ}\right)=\frac{0.22\left(T_{a} M_{a}+T_{c} M_{c}\right)+T_{w} M_{w}+T_{w a} M_{w a}-112 M_{i}}{0.22\left(M_{a}+M_{c}\right)+M_{w}+M_{w a}+M_{i}}
\end{aligned}
$$

where $M i$ is the mass in $\mathrm{kg}(\mathrm{lb})$ of ice (NRMCA 1962 and Mindess and Young 1981). Even crushed ice being charged into a truck mixer prior to the addition of other materials. Mixing time should be long enough to completely melt the 


\section{International Journal of Science and Research (IJSR) \\ ISSN (Online): 2319-7064}

Index Copernicus Value (2013): 6.14 | Impact Factor (2014): 5.611

ice. The volume of ice should not replace more than approximately $75 \%$

Table 1B (Metric) Effect of Ice (44 Kg ) on temperature of Concrete

\begin{tabular}{|c|c|c|c|c|c|}
\hline Material & Mass, $M, \mathrm{~kg}$ & $\begin{array}{l}\text { Specific heat } \\
\mathrm{kJ} / \mathrm{kg} \cdot \mathrm{K}\end{array}$ & $\begin{array}{c}\text { Joules to vary } \\
\text { temperature, } 1^{\circ} \mathrm{C}\end{array}$ & $\begin{array}{l}\text { Initial temperature } \\
\text { of material, } T,{ }^{\prime} C\end{array}$ & $\begin{array}{l}\text { Total joules } \\
\text { in material }\end{array}$ \\
\hline & (1) & (2) & $\begin{array}{c}\text { (3) } \\
\text { Col.1 } \times \text { Col. } 2\end{array}$ & (4) & $\begin{array}{c}\text { (5) } \\
\text { Col. } 3 \times \mathrm{COOl}^{4} 4\end{array}$ \\
\hline Cement & $335\left(M_{c}\right)$ & 0.92 & 308 & $66\left(T_{C}\right)$ & 20,328 \\
\hline Water & $123\left(M_{s}\right)$ & 4.184 & 515 & $27\left(T_{a}\right)$ & 13,905 \\
\hline Total aggregate & $1839\left(M_{2}\right)$ & 0.92 & 1692 & $27\left(T_{T}\right)^{\prime}$ & 45,684 \\
\hline & $44\left(M_{i}\right)$ & 4.184 & 184 & $0(\pi)$ & 0 \\
\hline minus & $44\left(M_{i}\right) \times t$ & t tusion, $1335 \mathrm{~kJ} / \mathrm{h}$ & 2699 & & $\frac{-14,740}{65,177}$ \\
\hline
\end{tabular}

of the total batch water. The maximum temperature reduction from the use of ice is limited to about $11^{\circ} \mathrm{C}$ $\left(20^{\circ} \mathrm{F}\right)$. If a greater temperature reduction is required, the injection of liquid nitrogen into the mixer may be the best alternative method. Aggregates have a pronounced effect on the fresh concrete temperature because they represent $70 \%$ to $85 \%$ of the total mass of concrete. To lower the temperature of concrete $0.5^{\circ} \mathrm{C}\left(1^{\circ} \mathrm{F}\right)$ requires only a $0.8^{\circ} \mathrm{C}$ to $1.1^{\circ} \mathrm{C}\left(1.5^{\circ} \mathrm{F}\right.$ to $\left.2^{\circ} \mathrm{F}\right)$ reduction in the temperature of the coarse aggregate.

A cement temperature change of $5^{\circ} \mathrm{C}\left(9^{\circ} \mathrm{F}\right)$ generally will change the concrete temperature by only $0.5^{\circ} \mathrm{C}\left(1^{\circ} \mathrm{F}\right)$. Because cement loses heat slowly during storage, it may still be warm when delivered. (This heat is produced in grinding the cement clinker during manufacture.) Since the temperature of cement does affect the temperature of the fresh concrete to some extent, some specifications place a limit on its temperature at the time of use. This limit varies from $66^{\circ} \mathrm{C}$ to $82^{\circ} \mathrm{C}\left(150^{\circ} \mathrm{F}\right.$ to $180^{\circ} \mathrm{F}$ ) (ACI Committee 305$)$.

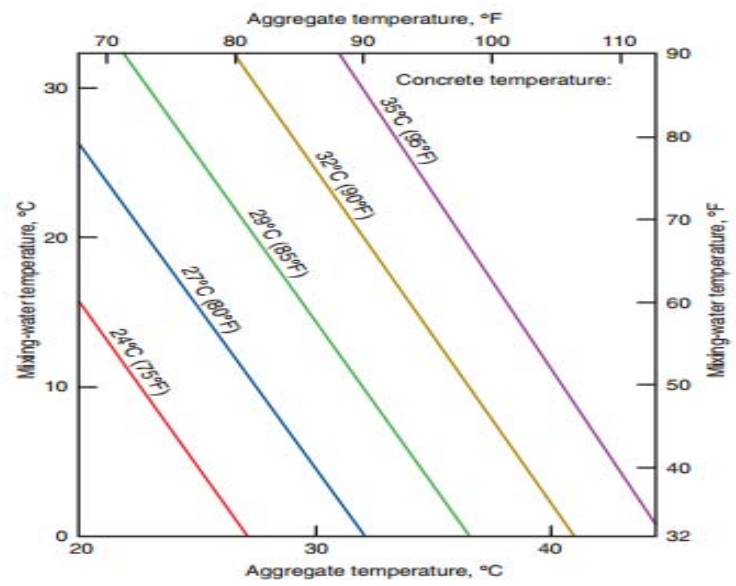

Figure 6: Temperature of freshly mixed concrete as affected by temperature of its ingredients. Although the chart is based on the following mixture, it is reasonably accurate for other typical mixtures.

Aggregate $1360 \mathrm{~kg}(3000 \mathrm{lb})$, Moisture in aggregate $27 \mathrm{~kg}$ (60 lb), Added mixing water $109 \mathrm{~kg}(240 \mathrm{lb})$, Cement at $66^{\circ} \mathrm{C}\left(150^{\circ} \mathrm{F}\right) 256 \mathrm{~kg}(564 \mathrm{lb})$

\subsection{Supplementary Cementitious Materials}

Many concrete producers consider the use of supplementary cementitious materials to be essential in hot weather conditions. The materials of choice are fly ash and other pozzolans (ASTM C 618 or AASHTO M 295) and ground granulated blast-furnace slag (ASTM C 989 or AASHTO M 302). These materials generally slow both the rate of setting as well as the rate of slump loss.

\section{Preparation before Concreting}

Certain precautions should be taken during hot weather before concrete is placed to maintain or reduce concrete temperature. Mixers, chutes, conveyor belts, hoppers, pump lines, and other equipment for handling concrete should be shaded, painted white, or covered with wet burlap to reduce solar heat. Forms, reinforcing steel, and subgrade should be fogged or sprinkled with cool water just before the concrete is placed. Fogging the area during placing and finishing operations not only cools the contact surfaces and surrounding air but also increases its relative humidity. This reduces the temperature rise of the concrete and minimizes the rate of evaporation of water from the concrete after placement. During extremely hot periods, improved results can be obtained by restricting concrete placement to early morning, evening, or night time hours, especially in arid climates. This practice has resulted in less thermal shrinkage and cracking of thick slabs and pavements.

\subsection{Transporting, Placing, Finishing}

Transporting and placing concrete should be done as quickly as practical during hot weather. Delays contribute to loss of slump and an increase in concrete temperature. Sufficient labor and equipment must be available at the jobsite to handle and place concrete immediately upon delivery.

Prolonged mixing, even at agitating speed, should be avoided. If delays occur, stopping the mixer and then agitating intermittently can minimize the heat generated by mixing. ASTM C 94 (AASHTO M 157) requires that discharge of concrete be completed within 90 minutes or before the drum has revolved 300 times, whichever occurs first. During hot weather the time limit can be reasonably reduced to 60 minutes or even 45 minutes.

\section{Plastic Shrinkage Cracking}

Plastic shrinkage cracks sometimes occur in the surface of freshly mixed concrete soon after it has been placed, while it is being finished or shortly thereafter (Fig.7). These cracks which appear mostly on horizontal surfaces can be substantially eliminated if preventive measures are taken. Plastic shrinkage cracking is usually associated with hot weather concreting; however, it can occur any time ambient conditions produce rapid evaporation of moisture from the concrete surface. These cracks occur when water evaporates from the surface faster than it can travel to the surface during the bleeding process. This creates rapid drying shrinkage and tensile stresses in the surface that often result in short, irregular cracks. The following conditions, singly or collectively, increase evaporation of surface moisture and increase the possibility of plastic shrinkage cracking:

1. Low air temperature, 2. High concrete temperature, 3. Low humidity, 4. High wind speed 


\section{International Journal of Science and Research (IJSR) \\ ISSN (Online): 2319-7064}

Index Copernicus Value (2013): 6.14 | Impact Factor (2014): 5.611

The crack length is generally 50 to $1000 \mathrm{~mm}$ (a few inches to $3 \mathrm{ft}$ ) in length and they are usually spaced in an irregular pattern from 50 to $700 \mathrm{~mm}$ (a few inches to $2 \mathrm{ft}$ ) apart. Fig. 8 is useful for determining when precautionary measures should be taken. There is no way to predict with certainty when plastic shrinkage cracking will occur.

When the rate of evaporation exceeds $1 \mathrm{~kg} / \mathrm{m} 2(0.2 \mathrm{lb} / \mathrm{ft} 2)$ per hour, precautionary measures such as wind screens re almost mandatory. With some concrete mixtures such as those containing pozzolans, cracking is possible if the rate of evaporation exceeds $0.5 \mathrm{~kg} / \mathrm{m} 2 \quad(0.1 \mathrm{lb} / \mathrm{ft} 2)$ per hour. Concrete containing silica fume is particularly y prone to plastic shrinkage because bleeding rates are commonly only $0.25 \mathrm{~kg} / \mathrm{m} 2(0.05 \mathrm{lb} / \mathrm{ft} 2)$ per hour. Therefore, protection from premature drying is essential at lower evaporation rates. At some point in the process of setting, bleeding goes to zero and the surface begins to dry at evaporation rates much lower than the typically specified $1.0 \mathrm{~kg} / \mathrm{m} 2 \quad(0.2$ $\mathrm{lb} / \mathrm{ft} 2$ ) per hour.

Below precautions listed below can minimize the occurrence of plastic shrinkage cracking.

1. Moisten concrete aggregates that are dry and absorptive, 2. Keep the concrete temperature low by cooling aggregates and mixing water. 3. Dampen the subgrade and fog forms prior to placing concrete. 4 . Erect temporary windbreaks to reduce wind velocity over the concrete surface. 5. Erect temporary sunshades to reduce concrete surface temperatures. 6. Protect the concrete with temporary coverings, such as polyethylene sheeting, during any appreciable delay between placing and finishing.

Fogging the concrete before and after final finishing is the most effective way to minimize evaporation and reduce plastic shrinkage cracking. Use of a fog spray will raise the relative humidity of the ambient air over the slab, thus

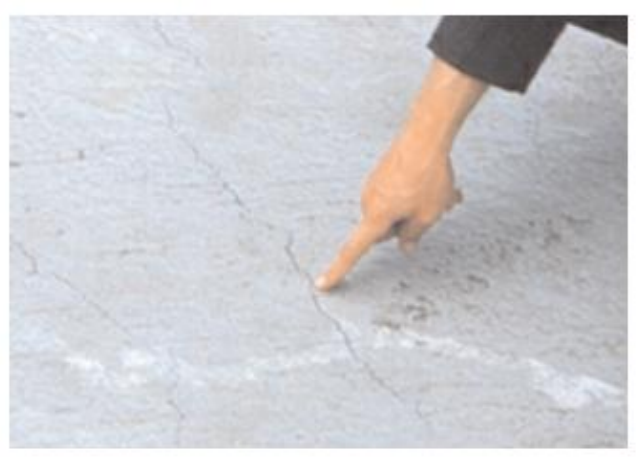

Figure 7: Typical plastic shrinkage cracks

reducing evaporation from the concrete. Fog nozzles atomize water using air pressure (Figs. 9 ) to create a fog blanket.

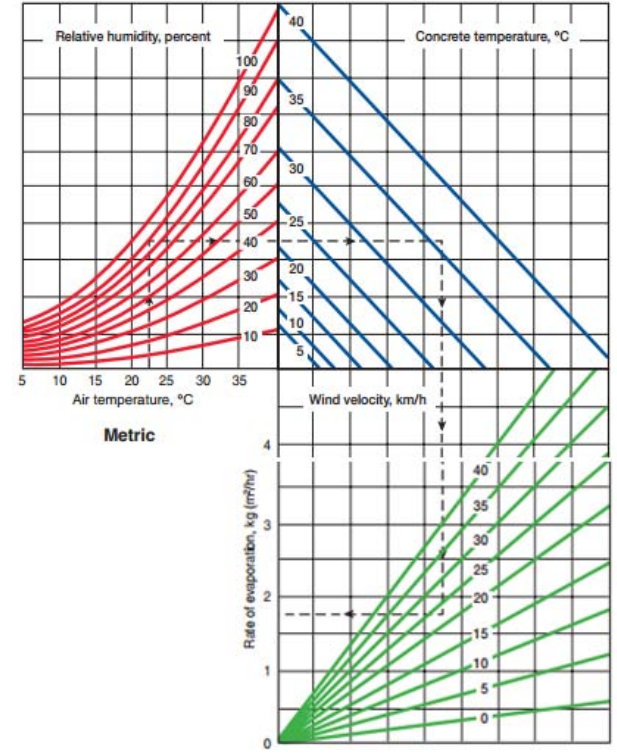

Figure 8

Figure 8. Start at air temperature, draw a vertical line up to relative humidity, then a horizontal line to the right to concrete temperature, then go vertically down to wind velocity, and horizontally to the left to determine the evaporation rate. If the evaporation rate is greater than 0.1 , plastic shrinkage cracking is likely.

\subsection{Curing And Protection}

Curing and protection are more critical in hot weather than in temperate periods. On hardened concrete and on flat concrete in particular, curing water should not be more than about $11^{\circ} \mathrm{C}\left(20^{\circ} \mathrm{F}\right)$ cooler than the concrete. This will minimize cracking caused by thermal stresses due to temperature differentials between the concrete and curing water.

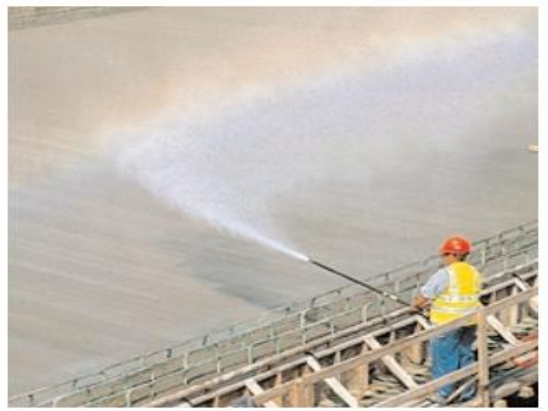

Figure 9: Fogging cools the air and raises the relative

humidity above flatwork to lessen rapid evaporation from the concrete surface, thus reducing cracking and improving surface durability. The need for moist curing is greatest during the first few hours after finishing. To prevent the drying of exposed concrete surfaces, moist curing should commence as soon as the surfaces are finished and continue for at least 24 hours. In hot weather, continuous moist curing for the entire curing period is preferred.

\section{Admixtures}

For unusual cases in hot weather and where careful inspection is maintained, a retarding admixture may be 


\section{International Journal of Science and Research (IJSR) \\ ISSN (Online): 2319-7064}

Index Copernicus Value (2013): 6.14 | Impact Factor (2014): 5.611

beneficial in delaying the setting time, despite the somewhat increased rate of slump loss resulting from their use. A hydration control admixture can be used to stop cement hydration and setting. Hydration is resumed, when desired with the addition of a special accelerator (reactivator). Retarding admixtures should conform to the requirements of ASTM C 494 (AASHTO M 194) Type B.

\subsection{Heat of Hydration}

Heat generated during cement hydration raises the temperature of concrete to a greater or lesser extent depending on the size of the concrete placement, its surrounding environment, and the amount of cement in the concrete. As a general rule a $5^{\circ} \mathrm{C}$ to $9^{\circ} \mathrm{C}\left(10^{\circ} \mathrm{F}\right.$ to $\left.15^{\circ} \mathrm{F}\right)$ temperature rise per $45 \mathrm{~kg}(100 \mathrm{lb})$ of Portland cement can be expected from the heat of hydration (ACI Committee 211 1997). There may be instances in hot-weather-concrete work and massive concrete placements when measures must be taken to cope with the generation of heat from cement hydration and attendant thermal volume changes to control cracking.

\section{Conclusion}

Detailed planning for hot weather concrete is essential. A pre-placement meeting is recommended to clarify requirements to address the wide range of possible actions and discuss the plan to control the effects specific to the project and expected conditions to define responsibilities. These may include use of materials with a good performance history in high temperature conditions, cool concrete materials or concrete mixture, provide concrete consistency and placement equipment and crew for rapid placement, reduce time of transport, schedule placement to limit exposure to atmospheric conditions plan to limit rapid moisture loss (sun screens, wind screens, misting, or fogging), and consider the use of an evaporation retarder. To summarize, adequate measures at every step involved in concreting from material storage, concrete mixing, transportation, placing, finishing, curing and concrete cube casting as mentioned above to be undertaken if done during HOT WEATHER for better and durable concrete.

\section{Acknowledgment}

The research and presented in this paper has been funded by several organizations. Mainly Prof. S.K.M. Rao, Principal of Siddhartha Institute of Engineering and Technology through the strategic institute program SIETRP should be acknowledged. Special thanks goes to the. Prof. T. Appa Reddy, RGMCET, AP, India, who provided insight and expertise that greatly assisted and helping in carrying out my research work.

\section{References}

[1] Klieger, Paul, Effect of Mixing and Curing Temperature on Concrete Strength, Research Department Bulletin RX103, Portland Cement Association,.pdf, 1958.
[2] ACI Committee 308, Standard Specification for Curing Concrete, ACI 308.1-98, American Concrete Institute, Farmington Hills, Michigan, 1998, 9 pages.

[3] Lerch, William, Hot Cement and Hot Weather Con- crete Tests IS015, Portland Cement Association.pdf, 1955.

[4] Menzel, Carl A., "Causes and Prevention of Crack Development in Plastic Concrete," Proceedings of the Portland Cement Association, 1954, pages 130 to 136.

[5] Mindess, Sidney, and Young, J. Francis, Concrete, Prentice Hall, Englewood Cliffs, New Jersey, 1981.

[6] NRMCA, Cooling Ready Mixed Concrete, NRMCA Publication No. 106, National Ready Mixed concrete Association, Silver Spring, Maryland, 1962.

\section{Author Profile}

Dr. S. Vijaya Mohan Rao, did his B.Tech.(Civil) and M.Tech in Structural Engineering and obtained $\mathrm{PhD}$ in Retrofitting of structures. He has 13 Years of Industrial Experience in Middle East and 15 Years of Teaching Experience. He has wide knowledge of RCC structures, Properties and behaviour of concrete, and his articles published in various journals. At present he is working as Professor and Head of Department in "Siddhartha Institute of Engineering \& Technology", Hyderabad, Telangana state, India 